GLOBAL JOURNAL OF AGRICULTURAL SCIENCES VOL. 18, 2019: 13-18

COPYRIGHT@ BACHUDO SCIENCE CO. LTD PRINTED IN NIGERIA ISSN 1596-2903

www.globaljournalseries.com, Email: info@globaljournalseries.com

\title{
CHEMICAL COMPOSITION OF TOASTED AND FERMENTED EARTH BALL (Icacinia manni) MEALS: DETERMINATION OF THEIR FEEDING VALUE USING BROILER CHICKENS.
}

\author{
EFFIONG, O. O. AND JIMMY, N. P
}

(Received 9 January 2019; Revision Accepted 11 February 2019)

\begin{abstract}
The study compared the chemical composition of fermented and toasted Icacina manni meal and evaluated their feeding and economic values using broiler chickens. The harvested roots were processed under two methods: the first involved peeling, chopping and fermentation of the roots for 48hours, while in second method, peeled tubers were grated and the liquid component squeezed out prior to toasting. Three diets each were formulated at starter and finisher phase of production, with diet one as the control. Diets two and three had $30 \%$ of maize replaced by fermented I. Manni and toasted I. manni meals, respectively. One hundred and thirty five day old broiler chicks were divided into three groups of forty five chicks, randomly allocated to the three experimental diets in a completely randomized design and fed for 28 days each of starter and finisher phase. Data generated were analysed using the general linear models procedure of SPSS options, Version 18.00 (SPSS Inc., 2010). The result revealed that I. manni samples were similar $(P>0.05)$ to maize in ash and carbohydrate components. The processing methods significantly $(P<0.05)$ reduced the levels of anti-nutrients in the samples, except for phytates, with the fermentation method causing the highest reduction in the anti-nutrients levels. At the starter phase, birds on control diet recorded superior $(P<0.05)$ average daily feed intake and weight gain while the feed conversion ratio (FCR) values were not influenced by the treatment at both phases of production. The dressing percentage and relative weights of the cut parts and internal organs were not $(P>0.05)$ influenced by the treatment. The dietary inclusion of $I$. manni meals reduced the cost of feed production by $50 \%$, the cost of feed consumed from $\$ 135.96$ to 42.35 and 57.41 in toasted and fermented $I$. manni diets, respectively and the cost of producing a kilogram of meal at the starter phase. From the economic perspective, it was concluded that toasting could serve as an alternative method of processing $I$. manni meal for poultry feeding.
\end{abstract}

KEY WORDS: Anti-nutritional factors, toasting, fermentation, Icacina manni, performance, carcass characteristics.

\section{INTRODUCTION}

Maize and to a lesser extent sorghum, which serve as conventional sources of energy in animal feeds are difficult to secure due to stiff competition for them by man as staple food and for industrial purposes. Severe drought and insufficient supply of fertilizer have made maize. Sorghum and guinea corn cultivation difficult, with a consequent high cost, which poor and small scale livestock farmers are unable to afford. For instance, the price of maize has risen to $\$ 150,000$ per ton in Cross River State of Nigeria from $\$ 60,000 /$ ton sold in 2006. One way of solving this problem has been the use of non-conventional energy resources like cassava, cocoyam and potatoes which according to Eustace, (1991) can replace up to $50 \%$ of maize in diets of poultry and pigs. These sources are also becoming scarce and expensive and most times not readily available as they are also utilized for industrial purposes. For instance, cassava root is used to ferment drinks and is also exported out of Nigeria as chips to earn foreign exchange. In 2006, the Nigerian former President Olusegun Obasanjo made it mandatory for every flour miller in the country to include at least $10 \%$ of cassava in flour processing. In 2013, the bank of industry came into agreement with the Federal Government of Nigeria that up to $20 \%$ of cassava should be included in flour milling for bread making (FMARD, 2012).

In order to reduce the burden created by the scarcity of these feed resources, it is necessary for animal nutritionists to again look inward for other locally available, cheaper, less competitive and nutritionally adequate substitutes, which are not utilize by man. Icacinia manni (earth ball), a root tuber grown naturally in the wild, having a close resemblance with cassava tuber has been exploited in this respect. The proximate analysis reported by Umoren et al. (2007) showed that the raw tuber contained $5.69 \%$, Crude protein, $16 \%$ crude fibre, $3.60 \%$ ether extract and $12 \%$ ash. The authors also gave $2276.86 \mathrm{KcalME} / \mathrm{kg}$ as the metabolizable energy of the raw I. manni. Umoren et al., (2008) noted that the raw I. manni is rich in macro minerals; calcium $(0.11 \mathrm{mg} / \mathrm{g})$, magnesium $(0.09 \mathrm{mg} / \mathrm{g})$, sodium $(0.18 \mathrm{mg} / \mathrm{g})$, potassium $(0.97 \mathrm{mg} / \mathrm{g})$, copper $(1.00 \mathrm{mg} / \mathrm{g})$ and iron $(0.17 \mathrm{mg} / \mathrm{g})$ as well as manganese $(0.09 \mathrm{mg} / 100 \mathrm{~g})$.

Effiong, O. O., Department of Animal Science University of Calabar- Nigeria.

Jimmy, N. P., Department of Animal Science University of Calabar- Nigeria. 
Despite the rich nutritional potentials, studies (Umoren et al., 2008; Effiong et al., 2014 and Effiong and Akpan, 2017) indicated that I. manni like other tuberous crops contained anti-nutritional factors, including hydrocyanic acid, phytates, tannins and oxalates which limit its use as animal feeding stuff. Processing method such as fermentation has been employed in reducing the profile of these anti-nutritional factors in the tuber. In the tropics, sun drying of the fermented sample posed a problem due to the high rain fall and high relative humidity prevalent in this region, resulting in a low quality feedstuff.

In this research therefore, the use of toasting as alternative processing method was evaluated.

\section{Objectives of the study}

This study was designed to compare the effects of toasting and fermentation on the chemical composition of Icacinia manni and to evaluate their feeding and economic values using broiler chickens.

\section{MATERIALS AND METHODS}

\section{Experimental site}

The experiment was conducted at the poultry unit of the Teaching and Research Farm, University of Calabar, Calabar, Cross River State.

Collection and processing of experimental materials The Icacina manni tubers were harvested during dry season from fallow lands in the wild at Akpabuyo Local Government Area of Cross River State of Nigeria and processed under two methods.

In the first method, the tubers were peeled, chopped into chips or pieces and fermented in plastic buckets for 48hours. After 48hours, the fermented sample was rinsed with clean water, sun- dried and milled.

Tubers in the second group were peeled, grated, packed in a jute bag and pressed with stone to squeeze out liquid component for about 12 hours. The dehydrated sample was there after toasted to dry out at about 20 minutes in a garri frying pot on open fire. The processed samples were properly labeled and stored in an air tight plastic container until needed for chemical analysis and for feed formulation.

\section{Proximate analysis of the test samples}

The proximate chemical compositions of the fermented and toasted Icacina meals were determined using the methods as outlined by (AOAC, 2005). The crude protein, crude fibre, ether extract, and ash, were determined on dry matter basis, while the nitrogen free extract was determined as a difference.

\section{Determination of anti-nutritional factors}

The anti-nutritional factors of the raw and processed $I$. manni were analyzed. Hydrocyanic acid was determined by modified alkaline titration method (AOAC, 1990). Titration of distillate was carried put with $2.02 \mathrm{~m}$ sodium thio-sulphate using $1 \mathrm{ml}$ iodine and a drop of starch as the indicator. Total oxalate content was determined by the procedure of Abaga et al. (1968), while the extraction and precipitation of phytic acid was performed according to the method described by Grewal and Jood (2006).

\section{Composition of experimental diets}

Three experimental diets (Table 1) were formulated to supply 23 per cent crude protein; $2800 \mathrm{kcalME} / \mathrm{kg}$ and 20 per cent crude protein and $3000 \mathrm{kcalME} / \mathrm{kg}$ of metabolizable energy, at the starter and finisher phases respectively. Diet one was the control diet without the test samples while diets two and three had $30 \%$ of maize replaced by fermented and toasted I. manni, respectively.

\section{Experimental birds and design}

One hundred and thirty five day old unsexed broiler chicks were purchased from FIDAN hatchery and used for this experiment. The birds were weighed individually and grouped according to their body weights into three groups of 45 chicks. Each group was sub divided into three replicates with fifteen chicks per replicate. Groups were randomly allotted to the three starter diets in a completely randomized design. At the end of the brooding period (day 28), broiler finisher diets were introduced to the birds on the respective treatment groups and were fed until the end of the experiment (day $56)$.

\section{Data collection and analysis}

Feed intake on replicate basis was measured daily, while the weights of the birds were taken on weekly basis. Feed intake and weight gain were used to calculate the feed conversion ratio on weekly basis.

At the end of growth trial, two birds per replicate (six birds per treatment), with weights closer to the average weight of the population were selected, fasted for 12 hours, individually weighed, slaughtered and eviscerated. The weight of the liver, proventiculus, heart, gizzard, and intestine were taken and expressed as percentage of live weight. The birds were also divided into different parts (neck, breast, back, thigh, shank and wing) and weighed individually and also expressed as percentage live weight.

Data collected were subjected to a one way analysis of variance in a completely randomized design (CRD). Significant means were separated using Duncan's multiple range test (Duncan, 1956)

\section{RESULTS AND DISCUSSION}

\section{Proximate composition}

The proximate compositions of toasted and fermented $I$. manni meals compared to maize are presented in Table 2.

Results showed no significant $(P>0.05)$ differences in the composition of crude protein, fibre, ether extract, ash and carbohydrate between toasted and fermented $I$. manni meals. The I. manni samples were however inferior $(P<0.05)$ to maize in their crude protein, ether extract and crude fibre contents but were statistically $(P>0.05)$ similar to maize in ash and carbohydrate contents. The high contents of ash and carbohydrate recorded in the I. manni meals indicated that they are good dietary sources of minerals and energy in animal's feed. The two processing methods were observed to maintain could retain the nutritive value of $I$. manni meal in line with the report of (Effiong et al., 2014).

\section{Anti-nutritional factors composition}

The quantitative values of the anti-nutritional factors of the raw and processed I. manni are presented in Table 
The two processing methods significantly $(P<0.05)$ reduced the anti-nutrient contents in the samples, except for phytates, whose concentration increased with from $22.05 \mathrm{mg} / 100 \mathrm{~g}$ in raw sample to 26.59 and 30.81 for fermented and toasted samples. This may be attributed to the stable nature of the phytate when exposed to heat treatment. The result compares favorably with the work of Makkar et al. (1998) on the effect of roasting on the anti-nutrients and toxic factors of Jatropha curcas (Oladele and Oshodi, 2008) on the effect of fermentation on some chemical and nutritive properties of berlandier nettle spurge (Jatropha cathartica) and physic nut (Jatropha curcas) seeds. These authors observed that phytate levels were either similar or higher for the roasted and fermented seeds. Fermentation caused the highest reduction in the antinutrients levels compared to the toasting method never the less, the concentrations of these compounds in the toasted sample were within the safety limits recommended for animals (Effiong et al., 2014).

\section{Performance of broiler chickens fed diets containing toasted and fermented $I$. manni meals.}

The performance of broiler chickens fed diets containing toasted and fermented $I$. manni meals are presented in Table 4.

At the starter phase, birds on control diet recorded the highest $(P<0.05)$ average daily feed intake $(46.91 \mathrm{~g})$ while the least average daily feed intake $(24.75 \mathrm{~g})$ was observed among birds fed $30 \%$ toasted $I$. manni diet. The low feed intake observed, particularly with birds on toasted $I$. manni meal diet maybe attributed to the presence of anti-nutritional factors like tannins reported to adversely affect feed intake (Umoren et al., 2007); Suleiman, (2017). Lack of palatability in the feed due to the presence of anti-nutritional factors, dustiness (Umoren et al., 2008; and Effiong et al., 2014) and the bulky nature of the feed sample (Jafarnejad et al., 2010) may have also contributed to the low intake of the feeds with I. manni meal. At the finisher phase, the average daily feed intake of birds fed control diet was statistically $(P>0.05)$ similar to those of the treatment groups.

Birds fed control diet had a superior average daily weight gain $(21.93 \mathrm{~g})$ compared to those on diets with $30 \%$ each of toasted $(10.30 \mathrm{~g})$ and fermented $I$. manni $(14.38 \mathrm{~g})$. The depressed weight gain noted among birds fed the treatment diets may be attributed to the low protein and amino acids digestibility attributed to the presence of tannins Galani et al. (2005). Reduction in feed intake could also have contributed to a reduced growth response. Tucker (2006), Clack (2009) and Choct (2009) stated that the gut health is critical and that the relationship between gut health and growth performance is crucial, especially in young birds. The authors further stated that depression in feed intake could be hinder gut development, allowing for increased endogenous losses and drawing of valuable nutrients out of the body reserves for the development.

Performance of birds fed fermented I. manni diet was better than those fed toasted I. manni diet at starter phase, but compared favorably at finisher phase. The average daily weight gain of $10.30 \mathrm{~g}$ for birds on toasted I. manni diet and $14.38 \mathrm{~g}$ for birds on fermented I. manni diet at starter phase were lower than $52.5-55 \mathrm{~g}$ reported by Uchegbu et al. (2011) for broiler chicks fed cassava root meal and maize/sorghum brewers dried meal diet.
Ukachukwu (2008) and Zanu (2017), reported the average daily weight gain, ranging from 33.65 to $35.86 \mathrm{~g}$ and $36.95 \mathrm{~g}$ for broiler chickens fed diets containing composite cassava supplemented with or without palm oil/or methionine and cassava peel meal supplemented with palm oil, respectively at finisher phase. The values reported by these authors were similar to those obtain in this experiment.

The birds on fermented I. manni meal and those on toasted I. manni meal recorded similar $(P>0.05)$ feed conversion ratio (FCR) at the starter and the finisher phases. Birds on treatment diets were equally efficient in converting their feeds into meat as those fed the control diet as showned in similarities in the FCR values. The FCR values recorded in this work were similar to the recommended value of 2.5 by Oluyemi and Robert (2000) at starter phase. The FCR range of $2.14-2.59$ and 3.23-3.82 observed in the starter and finisher phases of this experiment were also similar to the FCR values of 2.41-3.61, 3.10-3.78 and 2.52 - 3.03 reported by Ojewola et al. (2006), Effiong and Akpan, (2017), and Zanu et al. (2017) for broiler chickens fed diets containing cassava peel meal supplemented with palm oil, rumen filtrate fermented Icacina manni meal and cassava root flour meal, respectively. However the FCR values of this work were superior to 3.39 - 5.09 recorded by Ucheghu et al. (2011) for broiler chicks fed cassava root meal and maize/sorghum brewers dried meal diet.

\section{Carcass and internal organs characteristics of} broiler chickens fed Icacinia manni meal diets.

The results of the carcass and internal organs characteristics of broiler chickens fed Icacinia manni meal diets are shown in Table 5.

The results revealed that toasted and fermented earth ball meal diets did not significantly $(P>0.05)$ reduce the dressing percentage, back and breast weight relative to the control diet. The dietary treatments did not significantly $(P>0.05)$ influence the relative weights of the internal organs (gizzard, heart, proventiculus, liver and intestine) were not equally ( $P>0.05)$, indicating that there were no abnormalities or pathological lesion on the organs. Non-significant relationship in the carcass characteristics between birds fed treatment diets and those fed control diet implies that the weight gain by these birds was not as a result of the offal but due to the increase in the muscles as Carcass yield is an indicator of the quality and utilization of the diet.

\section{Economics of feeding toasted and fermented $I$. manni diets to poultry}

The dietary inclusion of the processed I. manni (Table 4) reduced the cost of feed production by $50 \%$ during starter phase (that is from 103.51 in the control diet to \#55.33 in the fermented and toasted I. manni diets). Variation in the cost of feed production was not $(P>0.05)$ significant at the finisher phase.

The dietary inclusion of I. manni reduced $(P<0.05)$ the cost of feed consumed from 135.96 in the control diet to 42.35 in toasted I. manni diet and 57.41 in fermented I. manni diet, respectively at starter phase. At the finisher phase, the cost of feed consumed was reduced from $\$ 357.91$ for birds on control diet to \#276.08 and 345.83 for birds on toasted I. manni diet and fermented $I$. manni diet, respectively. The difference 
in the cost of feed consumed by birds on fermented $I$. manni meal was not significantly $(P>0.05)$ different from that of birds on control diet.

The dietary inclusion of toasted and fermented $I$. manni meals reduced $(\mathrm{P}<0.05)$ the cost of producing a kilogram of meat at starter phase. At finisher phase, variations in the cost of producing a kilogram of meat were statistically similar across the treatment groups.

\section{CONCLUSION}

From the economic point of view, it was concluded that toasting could serve as an alternative method of processing Icacina manni meal for poultry feeding.

Table 1: Composition of experimental diets(g/kg)

\begin{tabular}{lcccccc}
\hline Ingredients & \multicolumn{3}{c}{ Starter diets } & \multicolumn{3}{c}{ Finisher diets } \\
\cline { 2 - 7 } & $\mathbf{0 \%}$ & $\mathbf{3 0 \%}$ T & $\mathbf{3 0 \%} \mathbf{~ F}$ & $\mathbf{0 \%}$ & $\mathbf{3 0 \%}$ T & $\mathbf{3 0 \%}$ F \\
\hline Maize & 495.70 & 346.99 & 346.99 & 579.70 & 405.79 & 405.79 \\
Icacina manni & - & 148.71 & 148.71 & - & 173.91 & 173.91 \\
Soybean meal & 357.30 & 357.30 & 357.30 & 271.30 & 271.30 & 271.30 \\
Fish meal & 15.00 & 15.00 & 15.00 & 15.00 & 15.00 & 15.00 \\
Palm kernel cake & 37.00 & 37.00 & 37.00 & 40.00 & 40.00 & 40.00 \\
Wheat offal & 60.00 & 60.00 & 60.00 & 80.00 & 80.00 & 80.00 \\
Methionine & 2.00 & 2.00 & 2.00 & 2.00 & 2.00 & 2.00 \\
Lysine & 2.00 & 2.00 & 2.00 & 2.00 & 2.00 & 2.00 \\
*Vitamin/mineral premix & 3.00 & 3.00 & 3.00 & 3.00 & 3.00 & 3.00 \\
Salt & 3.00 & 3.00 & 3.00 & 4.00 & 4.00 & 4.00 \\
Bone meal & 25.00 & 25.00 & 25.00 & 3.00 & 3.00 & 3.00 \\
\hline Total & $\mathbf{1 0 0 0 . 0 0}$ & $\mathbf{1 0 0 0 . 0 0}$ & $\mathbf{1 0 0 0 . 0 0}$ & $\mathbf{1 0 0 0 . 0 0}$ & $\mathbf{1 0 0 0 . 0 0}$ & $\mathbf{1 0 0 0 . 0 0}$ \\
\hline \% Crude protein & 23.00 & 22.50 & 22.45 & 20.00 & 19.50 & 19.45 \\
Metabolizable & & & & & 2900 \\
energyME/kcal/kg & 2850 & 2836 & 2837 & 3000 & 2985 & 2987 \\
\% Crude fibre & 3.19 & 4.70 & 4.98 & 4.39 & 5.82 & 5.87 \\
\hline
\end{tabular}

-Vitamin/ mineral premix containing the following per kg. Vitamin A 10,000000 I.U; Vitamin D3 2,000000I.U; Vitamin E 20,000IU; Vitamin K 2,250mg; Thiamine 1,750mg; Riboflavin B 5,000mg; Pyridoxine B6 2,750mg; Anti-oxidant 125g; Niacin 27,500mg; Vitamin B12 15mg; Pantothenic acid 7,500mg; Biotin 50mg; Choline chloride 400g, manganese 80g; Zinc 50g; 1ron 20g; copper, 5g; lodine 1.2g; Selenium 200mg; Cobalt 200mg

Table 2: Proximate composition of Icacina mani (\% dry matter)

\begin{tabular}{llllll}
\hline Sample & Crude protein & Crude fibre & Ether extract & Ash & Carbohydrate \\
\hline Toasted & $3.27^{\mathrm{b}}$ & $16.00^{\mathrm{a}}$ & $3.40^{\mathrm{b}}$ & 1.60 & 75.43 \\
fermented & $3.06^{\mathrm{b}}$ & $16.30^{\mathrm{a}}$ & $3.90^{\mathrm{b}}$ & 1.50 & 75.64 \\
Maize & $8.80^{\mathrm{a}}$ & $2.20^{\mathrm{b}}$ & $5.70^{\mathrm{a}}$ & 1.45 & 77.85 \\
\hline $\mathbf{\text { SSEM }}$ & $\mathbf{0 . 9 4}$ & $\mathbf{1 . 4 8}$ & $\mathbf{0 . 5 7}$ & $\mathbf{0 . 0 4}$ & $\mathbf{0 . 6 0}$ \\
\hline
\end{tabular}

Means with different superscripts on the same vertical line are significantly $(P<0.05)$ different

SEM- Standard error of means

Table 3: Anti nutritional factors composition of Icacina mani (mg/100g)

\begin{tabular}{|c|c|c|c|c|}
\hline Sample & $\begin{array}{l}\text { Hydrogen } \\
\text { cyanide }\end{array}$ & $\begin{array}{l}\text { Total } \\
\text { oxalate }\end{array}$ & $\begin{array}{l}\text { Soluble } \\
\text { oxalate }\end{array}$ & Phytates \\
\hline Raw & $16.46^{\mathrm{a}}$ & $305.60^{a}$ & $79.20^{a}$ & $22.05^{b}$ \\
\hline Toasted & $3.10^{b}$ & $114.00^{b}$ & $70.40^{a}$ & $26.59^{b}$ \\
\hline Fermented & $1.76^{c}$ & $79.20^{\mathrm{C}}$ & $49.72^{\mathrm{b}}$ & $30.81^{a}$ \\
\hline 土SEM & 1.49 & 5.75 & 2.03 & 1.09 \\
\hline
\end{tabular}

Means with different superscripts on the same vertical line are significantly $(P<0.05)$ different

SEM- Standard error of means 
Table 4: performance of broiler chickens fed diets containing I. manni meals

\begin{tabular}{|c|c|c|c|c|c|c|c|c|}
\hline \multirow{3}{*}{ Parameters } & \multicolumn{4}{|c|}{ Starter phase } & \multicolumn{4}{|c|}{ Finisher phase } \\
\hline & \multicolumn{4}{|c|}{ Levels of inclusion } & \multicolumn{4}{|c|}{ Levels of inclusion } \\
\hline & $0 \%$ & $30 \% \mathrm{~T}$ & $30 \% \mathrm{~F}$ & & $0 \%$ & $30 \% \mathrm{~T}$ & $30 \% \mathrm{~F}$ & 土SEM \\
\hline Initial weight/bird (q) & 4738 & 46.82 & 4750 & 031 & 46831 & 47022 & 46931 & 051 \\
\hline Final weight/bird (g) & $\begin{array}{l}41.30 \\
661.47\end{array}$ & $\begin{array}{l}40.02 \\
335.15\end{array}$ & 450.00 & 6.71 & $\begin{array}{l}400.51 \\
4\end{array}$ & 1386.41 & 1469.80 & 5.07 \\
\hline Total weight gain/bird (g) & 614.09 & 288.33 & 402.50 & 6.71 & $\begin{array}{l}1106.3 \\
9\end{array}$ & 916.19 & 1000.49 & 5.09 \\
\hline Av. daily weight gain/bird (g) & $21.93^{a}$ & $10.30^{c}$ & $14.38^{\mathrm{b}}$ & 1.28 & 39.51 & 32.72 & 35.73 & 0.96 \\
\hline Av. daily feed intake/bird (g) & $46.91^{\mathrm{a}}$ & $24.75^{\mathrm{c}}$ & $37.25^{\mathrm{b}}$ & 1.74 & 127.53 & 107.56 & 136.56 & 2.01 \\
\hline Feed conversion ratio & 2.14 & 2.40 & 2.59 & 0.24 & 3.23 & 3.29 & 3.82 & 0.30 \\
\hline \multicolumn{9}{|c|}{ Economics of feeding $I$. manni to broilers } \\
\hline Cost/kg of feed (\#) & $103.51^{\mathrm{a}}$ & $55.33^{b}$ & $55.33^{\mathrm{b}}$ & 2.75 & 100.67 & 91.67 & 90.67 & 1.22 \\
\hline Cost of feed consumed( & $135.96^{\mathrm{a}}$ & $42.35^{b}$ & $57.41^{\mathrm{b}}$ & 3.70 & $\begin{array}{l}357.91 \\
a\end{array}$ & $276.08^{b}$ & $345.83^{a}$ & 3.47 \\
\hline Cost/kg of weight gain ( & $221.40^{a}$ & ${ }_{b}^{132.99}$ & $143.39^{b}$ & 3.63 & 323.52 & 301.34 & 345.66 & 2.45 \\
\hline \multicolumn{9}{|c|}{$\begin{array}{l}\text { Means with different superscripts on the same horizontal line are significantly }(P<0.05) \text { different } \\
\text { SEM- Standard error of means }\end{array}$} \\
\hline \multicolumn{9}{|c|}{ levels of inclusion } \\
\hline Parameters & \multicolumn{2}{|c|}{$0 \% \quad 3$} & \multicolumn{2}{|c|}{$30 \% \mathrm{~T}$} & $30 \% \mathrm{~F}$ & \multicolumn{2}{|c|}{ ISEM } & \\
\hline Live weight $(\mathrm{g})$ & \multicolumn{2}{|c|}{1775} & 1225 & \multicolumn{2}{|r|}{1620} & \multicolumn{2}{|c|}{5.07} & \\
\hline Dressed weight(g) & 1250 & \multicolumn{2}{|c|}{920} & \multicolumn{2}{|r|}{1120} & \multicolumn{2}{|c|}{6.72} & \\
\hline Dressing percentage & 70.42 & \multicolumn{2}{|c|}{75.10} & \multicolumn{2}{|r|}{69.14} & \multicolumn{2}{|c|}{1.13} & \\
\hline \multicolumn{9}{|c|}{ Carcass characteristics (\% live weight) } \\
\hline Thigh & 19.43 & \multicolumn{2}{|c|}{20.39} & \multicolumn{2}{|r|}{20.51} & & & \\
\hline Back & 18.32 & & 0.10 & & 15.43 & 0. & & \\
\hline Wing & 8.88 & & 97 & & 9.57 & & & \\
\hline Neck & 6.62 & & 12 & & 6.01 & & & \\
\hline Head & 2.60 & & 89 & & 3.40 & & & \\
\hline Shank & 4.09 & & 90 & & 5.24 & & & \\
\hline Breast & 19.30 & & 5.09 & & 17.30 & & & \\
\hline Internal organs (\% live weig & & & & & & & & \\
\hline Gizzard & 3.38 & & 91 & & 4.02 & & & \\
\hline Heart & 0.59 & & 73 & & 0.61 & & & \\
\hline Liver & 2.53 & & 68 & & 2.79 & & & \\
\hline Proventiculus & 0.49 & & 58 & & 0.54 & & & \\
\hline Length of the intestine $(\mathrm{cm})$ & 231 & & & & 226 & & & \\
\hline
\end{tabular}

SEM- Standard error of means

\section{REFERENCES}

Abaga, R. H., Blake, J. K. and Fisher, E. J., 1968. Oxalate determination. Analytical problems encountered with certain plant species. Journal of AOAC. 51: 968-967.

AOAC 1990. Association of official analytical chemist's official methods of analysis. $15^{\text {th }}$ edition. AOAC. Incorporation Virginia USA.

AOAC 2005. Official methods of analysis. $18^{\text {th }} \mathrm{Ed}$. AOAC. Association of official analytical chemists. Washington DC.

Choct 2009. Managing gut health through nutrition. British poultry science (50): 9-15.
Clack 2009. Effect of feeding cracked corn and concentrate protein pellets on broiler growth performance. The journal of applied poultry research. 18(2):259-268.

Duncan, D. B., 1955. Multiple range and multiple Ftests. Biometrics. 11:1-48.

Effiong, O. O and Akpan, V. E., 2017. Performance of finisher broiler chickens fed diets containing graded levels of rumen digesta filtrate fermented earth ball Icacinia manni Journal of Agriculture and ecology research international. 13(2): 1-8. 
Effiong, O. O., Umoren, U. E. and Sylvester, G. D., 2014. Chemical composition of Icacinia manni earth ball meal: Nutritional potentials as energy source in broiler ration. Journal of animal production. 40(2):84-90.

Eustace, A. I., 1991. Unconventional feedstuff for livestock production. Proceedings, $8^{\text {th }}$ Annual Institute of Livestock in Development. New Windsor Service Centre Maryland, U.S.A. 11$16^{\text {th }}$

Federal ministry of agriculture and rural development FMARD 2012. Issues in agriculture: cashing on agricultural transformation agenda.

Gilani, G. S., Cockeel, K. A. and Sepear, E., 2005. Effect of antinutritional factors on protein digestibility and amino acids availability. Journal of AOAC international. 8 (3): 967-987

Grewal, A. and Jood, S., 2006. Effect of processing treatments on nutrient and anti-nutritional from Quintna Roo State of Mexico and Effect of roasting on anti-nutrient and toxic factors in seeds. Institute for Animal Production in the Tropics and Subtropics 480, University of Hohenheim, D-70593 Stuttgart, Germany.

Jafarnejad, M. F. and Bahonar, A. R., 2010. Effect of crumble-pellet and mash diet with different levels of dietary protein and energy on the performance of broilers at third week. Veterinary medicine international, 1-10.

Makkar, H. P. S., Becker, K. and B. Schmook, 1998. Edible Provenances of Jatropha curcas contents on green gram. Journal of food biochemistry 30:535-546.

Ojewola, G. S., Opara, O. E., and Ndukpu, O., 2006. The substitutional value of cassava meal supplemented and unsupplemented with palm oil for maize in broiler diets. Journal of animal and veterinary advances. 5 (6):478-482.

Okoye, F. C., Obioha, F. C. and Okeke, G. C., 1988. The substitution of sundried cassava peal meal for maize in broiler finisher diets. Journal of tropical agriculture. 6(10): 1-15.
Oladele, E. P. and Oshodi, A., 2008. Effect of fermentation on some chemical and nutritive 1qproperties of berlandier nettle spurge (Jatropha cathartica) and Physic nut Jatropha curcas seeds. Pakistan journal of nutrition.7 (2): 292-296.

Oluyemi, I. A. and Robert, F. A., 2000. Poultry production in warm climate. Spectrum book Ltd. Ibadan - Nigeria. 1-165.

Suleiman C., 2017. Tannins and their effects on poultry nutrition. International conference on agriculture, forest, food sciences and technologies, Capppadocia, Turkey.

Tucker, L., 2006. For poultry: Correct nutrient supply for a healthy gut. Feed international 27:14-15.

Uchegu M. C., Etuk, E. B., Omede, A. A., and Opara, M. N., 2011. Effect of replacing maize with cassava root meal and maize/sorghum brewers dried grains on the performance of starter broilers. Tropical and substropical agrosystems. 14 (1): 365-367

Ukachukwu, N., 2008. Effect of composite cassava meal with or without palm oil and/or methionine supplementation on broiler performance. Livestock research for rural development. 29 (4)

Umoren, U. E., Isika, M. A., Asanga, E. P. and Ezeigwe, P. N., 2007. Effect of replacement of maize with earth ball (Icacina manni) meal on the performance of broiler chickens. Pakistan Journal of Biological Science 10(14):2368-2373.

Umoren, U. E., Ukam, V. E., Akpet, S. O. and Udoekong, E. C., 2008. Evaluation of earth ball (Icacinia manni) meal as energy replacement for maize in the diet of rats. International journal for food Agricultural science and environment. 6(3): 289-293.

Zanu. H. K., Azametin, M. K. and Agare, D., 2017. Effects of dietary inclusion of cassava root flour in broiler diets on growth performance carcass characteristics and hematological parameters. International journal of livestock production. 8 (3): 28-32- 